\title{
Dental Anxiety Levels and Affecting Factors in 7-14 Years Old Children
}

\author{
Eda TÖREDİ \\ Ministry Of Health, Kırlkkale Yüksek Ihtisas Hospital, Nurse, Master Science, Kırlkkale/TURKEY \\ Prof. Yurdagül ERDEM* \\ Kirlkkale UniversityFaculty of Health Sciences, Department of Pediatric Nursing, Klrlkkale/TURKEY \\ *Corresponding Author: Prof. Yurdagül ERDEM, Kirlkkale UniversityFaculty of Health Sciences, \\ Department of Pediatric Nursing, Kirlkkale/TURKEY. Email: erdemyurd@ gmail.com
}

\begin{abstract}
Anxiety and oral-dental health applications deficiencies are the reasons on the base of this problem. There is no study about dental anxiety of children in nursing area. This study aimed to measure dental anxiety levels and affecting factors in 7-14 years old children.

In the collection of data, Socio-demographic form and "Children Anxiety Sensitivity Index" were used. DMFT index (Decay, Missed, Filled Teeth) was determined by the dentist during the dental examination. The study population was children between aged 7-14 years old who applied to an oral and dental health center, Kirlkkale/Turkey. In the power analysis performed in Minitab 16 program, the sample size was calculated as 408 children.

In this study, the levels of dental anxiety of children were found to be moderate. There was a statistically significant relationship between children's ages, the cause for admission to the oral and dental health center, the explanation of the operation will be performed and the level of dental anxiety. There was positive correlation between DMFT index and dental anxiety level. It was determined that age, maternal working status, toothbrushing habit, toothbrushing period, dental floss use, prolonged use of pacifiers in infancy, junk food style nutrition affected to DMFT index.
\end{abstract}

Keywords: Child, Dental Anxiety, Nursing, Dental Care, Anxiety

\section{INTRODUCTION}

Tooth decays are the most common childhood disease in the world. According to the World Health Organization, $60 \%$ to $90 \%$ of children in the world are affected by tooth decay, because of inadequate preventive practices, poor accessibility, inadequate, expensive or nonexistent protective oral health services, which are highest rates in middle income countries with increased consumption of sugar[1-3]. WHO has recommended the use of certain age or age bands enable international comparison of Member States in terms of oral health indicators. For this purpose, the recommended age for children is 5-6, 12, 15 years [1-4]. WHO has suggested that the use of 5-6 years of age shows changes in determining the rate of caries in the teeth surface of a tooth, much shorter than the changes in the permanent teeth in the other index ages.12 years old with all permanent teeth except for the third molar teeth is defined as global monitoring age in terms of establishing a reliable sample during primary school leaving and working within the school system. 15 years of age in the evaluation of gum disease indicators in adolescence is important because permanent teeth are exposed to the oral environment for 3-9 years[46].According to WHO, four levels of DMFT classification have been identified. DMFT: 1.2 and below are very low level; DMFT: 1.2-2.6 are low level; DMFT: 2.7-4.4 are intermediate level; DMFT:4.4 and above are very high level [6]. In comparison between the countries, there are large differences and a wide variety of changes have been observed. Such as DMFT: 3.0 for the Americas, 2.6 for the European region and 1.7 for Africa [7-9].

In most developed countries, although high tooth decay rates have shown a downward trend in the last 20 years depending on public health measures, including changing living conditions, lifestyles, it still remains a problem [7-9]. Popescu et al. (2013) in the study conducted in 
Romania, the dental anxiety frequency was found to be $22.68 \%$ in children between aged 612 years old, and there was a relation between dental anxiety and sugar consumption and oraldental health knowledge level [10]. Schuller et al. (2003) found that those with dental anxiety had poor compliance with dental care [11]. Esa et al. (2010) determined that a positive relationship between dental caries and dental anxiety [12]. In our country, the Turkish Statistical Institute (TUIK) in the Health Statistics Year (2014), the oral and dental health problems were among the first five diseases in children between $0-6$ year's old group, in children aged 7-14 years, oral and dental health problems were the first with $24.6 \%$ [13].In a study by Çubukçu and Ercan (2008), the mean Dental Anxiety Scale (DAS) value of all children was $7.7 \pm 3.1$ with moderate level of anxiety in 305 children aged 7-12 years[14]. Protective oral and dental health practices in our country are not yet common throughout the country, so children or adulthood patients only go to the dentist for treatment when they have dental complaints $[15,16,17]$. Throughout the world, it is known that the contribution of dental caries to the burden of all diseases in the mouth is ten times higher than that of periodontal diseases [18].Due to this problem in our country, the share of resources allocated for oral and dental health services is increasing in the health expenditures [19].

This study was conducted to determine dental anxiety levels and affecting factors in 7-14 years old children coming to an oral and dental health center.7-14 years; pre-adolescence period was chosen because it is the expected age to acquire health related habits, to be included in the 12year-old age group in which the permanent teeth are placed in the mouth, and to form a reliable sample considering the children in the school system. Dental anxiety studies for dental treatment in our country are very limited. There is no dental anxiety research related to dental treatment in the pediatric nursing area.

The following questions have been answered in this study.

1. What is the level of dental anxiety related to dental treatment for children aged 7-14?

2. Does dental anxiety due to dental treatment affect socio-demographic characteristics?

3. Does the oral health status (DMFT) affect socio demographic characteristics?

4. Is there any association between dental anxiety and oral health status (DMFT)?

\section{MeThOD}

\section{Participants}

This study was conducted as a descriptive study to determine the dental anxiety levels and affecting factors related to dental treatment on children between the ages of 7-14 who applied with any dental problem to the Pedodontics Clinic between June and September 2016 in Kırıkkale Oral and Dental Health Center. Sampling has not been selected and work has been continued until the sample size determined in the power analysis is reached. In the power analysis made, Minitab 16 program was calculated as 0.5 difference, 3.1 standard deviation, 1 type error level, 0.05 and 0.90 power, and 406 sample sizes for t-test. The study was completed with 408 children. In Turkey, Kirıkkale Oral and Dental Health Center serves with 16 outpatient clinics with 34 units, 3 operating units with 1 unit and 1 pedodontic (child) outpatient clinic with 3 units. There are 2 specialist pedodontists, 1 general practitioner, 1 nurse and 1 health officer in the pedodontics clinic. In the policlinic, fluoride application, fissure sealant, tooth extraction, root canal treatment, filling, moving place holder, tooth stone cleaning etc are done. An average 70 children are seen in the hospital daily. There is a playroom for children. Nursing services are the child's acceptance, preparation and follow-up during the process. In this study, $59.1 \%$ of the children were girls and $45.1 \%$ were between ages 7-9 years old. children 's mothers $(31.9 \%)$ were primary school graduates and most of them(74.3\%)did not work. Most of the fathers $(38 \%)$ were graduated from high school and $91.7 \%$ were working parents.

\section{Data Collection Method}

The data of the study were collected through face-to-face interviews using the Sociodemographic Data Form and the "Children Anxiety Sensitivity Index" (CASI).DMFT information was obtained from the dentist during the procedure at the outpatient clinic. The "Socio-Demographic Data Form" is a 30question form that includes demographic characteristics of children and their parents, oral-dental health practices.

CASI is a 15-item likert type scale developed by Fleisig, Rabian, and Peterson (1991) and reviewed by Jokić-Begić, Jurin and Korajlija (2011).This scale was conducted by Seçer and Gülbahçe (2013) in Turkish with validity and reliability studies, and the original version of the 
scale consists of three sub-dimensions [20]. As a result of the reliability analysis of the scale, internal consistency coefficient $\alpha=.87$ and test retest reliability $\mathrm{r}=.86$.It has been determined that the scale is a reliable and valid measuring instrument in a three-dimensional structure such as physical sensitivity, psychological sensitivity and social anxiety as it is in its original form. In addition to the sub-dimensions in the scale, the overall score for the scale is calculated. Subdimensions of the materials in the measurement; Psychological sensitivity of items 4, 8, 9, 10 and

Table1. Children's Anxiety Sensitivity Index and Subscale Score Averages

\begin{tabular}{|l|l|l|l|}
\hline & Minimum & Maximum & Mean \pm Sd \\
\hline Physical Sensitivity & 7.00 & 35.00 & $19.49 \pm 5.93$ \\
\hline Psychological Sensitivity & 5.00 & 25.00 & $15.50 \pm 4.34$ \\
\hline Social Anxiety & 3.00 & 15.00 & $8.85 \pm 3.42$ \\
\hline General Scale Total Score & 17.00 & 75.00 & $43.65 \pm 11.57$ \\
\hline
\end{tabular}

\section{Statistical Analysis}

Number, percentage, mean, frequency, percentile calculation, Chi-square, $\mathrm{t}$ test and ANOVA were used in the statistical evaluation of the data through SPSS 21 packet program.

\section{Ethical Dimension}

The researcher has paid for all the costs of this work. For this study got permission from Bozok University Faculty of Medicine Non-Invasive Clinical Investigations Decision of the Ethics Committee. The names of all children participating in the survey will not be announced, all parents and children are informed about the written and verbal work on an equal basis. They know to be able to leave without written approvals.

Table2. Children's Oral and Dental Health Practices
11; Physical susceptibility of items 1, 2, 3, 5, 6, 7 , and 13, and social anxiety subscale of items 12,14 , and 15 were measured. As the score on the scale increases, the level of anxiety increases [20].In this study, internal consistency of the scale was found between Cronbach Alpha coefficient $\alpha=.83$ and correlation with subscale total test score $r=.75$ to 1 . Also, in this study, averages points of Children Anxiety Sensitivity Index and subscales was determined as shown in Table 1.

\section{FINDING}

In this study, it determined that the most common cause of admission to a dental hospital of children $(25 \%)$ is tooth decay.

Children come to the dentist most often (75.7 $\%)$ when they have trouble. More than half of the children $(52.5 \%)$ were educated about oral and dental health and most of them $(74.3 \%)$ received this education from the school. The oral and dental health practices of children are presented in Table 2. 83.4\% of children stated that they were brushing their teeth. Of the children, $71.8 \%$ were brushing teeth twice a day in the morning and evening, $63.6 \%$ for at least 2 minutes and $46.6 \%$ the average age at which children start brushing their teeth is $2.18 \pm 0.89$. When children came to the dental clinic, they stated that they had anxiety about $68.4 \%$ before the procedure. Most children (65.6\%) said that they felt uneasiness.

\begin{tabular}{|l|c|c|}
\hline Toothbrushing status (N=408) & N & \% \\
\hline Brushing & 341 & 83.4 \\
\hline Don't brushing teeth & 67 & 16.6 \\
\hline Reasons for not brushing teeth(n=67) & 60 & 89.6 \\
\hline Lack of habit & 6 & 9.0 \\
\hline Untimely & 1 & 1.4 \\
\hline Do not need & & 71.8 \\
\hline Children's toothbrushing frequency (n=341) & 245 & 11.1 \\
\hline Morning and evening & 38 & 17.0 \\
\hline Morning-Noon-Evening & 58 & \\
\hline After eating something & & 36.4 \\
\hline Children's toothbrushing duration(n=341) & 124 & 63.6 \\
\hline Less than 1 min & 217 & \\
\hline At least 2 min & & 46.6 \\
\hline Children's toothbrushing style $(\mathbf{n}=\mathbf{3 4 1})$ & 159 & \\
\hline Up and down & & \\
\hline
\end{tabular}




\begin{tabular}{|l|c|c|}
\hline \multicolumn{2}{|c|}{} & \multicolumn{2}{|c|}{27.3} \\
\hline Right to left & 66 & 19.4 \\
\hline Round & 23 & 6.7 \\
\hline disorganized & & 75.7 \\
\hline Mouth rinsing condition (N=408) & 309 & 24.3 \\
\hline Yes & 99 & 84.1 \\
\hline No & & 15.9 \\
\hline Having toothbrush (N=408) & 343 & \\
\hline Yes & 65 & 5.2 \\
\hline No & & 94.8 \\
\hline Using dental floss & 21 & \\
\hline Yes & 387 & \\
\hline No & & \\
\hline
\end{tabular}

The mean score of the dental anxiety sensitivity index in the study was $43.65 \pm 11.57$ as show in Table 1. Accordingly, it has been determined that children have moderate concerns. When the dental anxiety sensitivity index subscale averages and general scale total point averages according to gender were examined, it was found that the difference was not significant $(\mathrm{p} \mid>0.05)$ According to this, the gender of children did not affect the sensitivity of anxiety. When General anxiety sensitivity index total point and subscale points according to the ages groups of children were examined, it was observed that children aged 7-9 years participating in the survey had higher mean scores of subscale and general scale in Table 3 . The physical sensitivity and social anxiety

Table3. General Anxiety Sensitivity Index Total Point and Subscale Points According To the Ages Groups of Children

\begin{tabular}{|c|c|c|c|c|}
\hline & Ages & Mean \pm Sd & $\mathrm{F}$ & p. \\
\hline \multirow[t]{3}{*}{ Physical Sensitivity } & $7-9$ & $20.50 \pm 6.20$ & 4.314 & .014 \\
\hline & $10-12$ & $18.63 \pm 5.77$ & & \\
\hline & 13 years and over & $18.87 \pm 5.21$ & & \\
\hline \multirow[t]{3}{*}{ Psychological Sensitivity } & $7-9$ & $15.79 \pm 4.27$ & 1.087 & .338 \\
\hline & $10-12$ & $15.10 \pm 4.40$ & & \\
\hline & 13 years and over & $15.69 \pm 4.35$ & & \\
\hline \multirow{3}{*}{$\begin{array}{l}\text { Social } \\
\text { Anxiety }\end{array}$} & $7-9$ & $9.32 \pm 3.35$ & 5.138 & .006 \\
\hline & $10-12$ & $8.17 \pm 3.53$ & & \\
\hline & 13 years and over & $9.19 \pm 3.09$ & & \\
\hline \multirow[t]{3}{*}{ General Scale Total Score } & $7-9$ & $45.46 \pm 11.87$ & 4.342 & .014 \\
\hline & $10-12$ & $41.56 \pm 11.27$ & & \\
\hline & 13 years and over & $44.25 \pm 10.76$ & & \\
\hline
\end{tabular}

Table4. General Anxiety Sensitivity Index Total Point and Subscale Points According to the Feeling of Anxiety of Children

\begin{tabular}{|l|l|l|l|l|l|}
\hline & $\begin{array}{l}\text { Feeling of } \\
\text { Anxiety }\end{array}$ & Mean \pm Sd & $\mathbf{t}$ & df & p \\
\hline \multirow{2}{*}{ Physical Sensitivity } & Yes & $20.61 \pm 5.79$ & 5.616 & 368 & .000 \\
\cline { 2 - 6 } & No & $17.02 \pm 5.51$ & & & \\
\hline \multirow{2}{*}{ Psychological Sensitivity } & Yes & $16.09 \pm 4.29$ & 4.048 & 383 & .000 \\
\cline { 2 - 6 } & No & $14.20 \pm 4.17$ & & & \\
\hline \multirow{2}{*}{$\begin{array}{l}\text { Social } \\
\text { Anxiety }\end{array}$} & Yes & $9.25 \pm 3.34$ & 3.516 & 394 & .000 \\
\cline { 2 - 6 } & No & $7.97 \pm 3.44$ & & & .000 \\
\hline \multirow{2}{*}{ General Scale Total Score } & Yes & $45.83 \pm 11.32$ & 5.382 & 344 & \\
\cline { 2 - 7 } & No & $38.89 \pm 10.71$ & & & \\
\hline
\end{tabular}

subscale total scores of the 7-9 age group were found to be statistically higher than the other ages groups $(p<0.05)$ in Table 3 . According to this result, it can be said that the anxiety of the younger children is higher than the other ages.

Also, it was determined that the difference between the explanation of treatment will be done and the physical sensitivity subscales (explanation $18.83 \pm 5.70$; don't explanation $20.66 \pm 6.18)$ and general anxiety sensitivity index (explanation $42.59 \pm 11.04$; don't explanation $45.65 \pm 12.33$ ) total point averages was statistically significant (p <0.05). Accordingly, it can be said that the disclosure of the treatment is important for reducing the anxiety of the children. 
The distribution of the anxiety sensitivity index total point and subscale points according to feeling of anxiety of children was given in Table 4. As show in Table 4, it was determined that the difference between general anxiety sensitivity index total point and subscale points according to feeling anxiety were statistically advanced level significant $(\mathrm{p}<0.01)$.

In this study, also the children's DMFT status was assessed under the control of the dentist. Average DMFT score was determined as $4.75 \pm$ 3.46 , varies between $0-23$. The difference between the mean DMFT score and gender was

Table5. DMFT Point Averages According to Children's Oral-Dental Health Practices

\begin{tabular}{|c|c|c|c|c|}
\hline Admission frequency & $\begin{array}{l}\text { DMFT Point average } \\
\pm \text { Sd }\end{array}$ & df & $\mathrm{F}$ & Sig. \\
\hline First time & $4.06 \pm 2.98$ & \multirow{3}{*}{2} & \multirow{3}{*}{1.334} & \multirow{3}{*}{.265} \\
\hline Routine (every 6 months) & $4.49 \pm 3.18$ & & & \\
\hline Have a complaint & $4.90 \pm 3.57$ & & & \\
\hline $\begin{array}{l}\text { Oral Dental Health Education } \\
\text { Status }\end{array}$ & & & $\mathrm{t}$ & \\
\hline Yes & $4.86 \pm 3.49$ & \multirow{2}{*}{392} & \multirow{2}{*}{.652} & \multirow{2}{*}{.515} \\
\hline No & $4.64 \pm 3.44$ & & & \\
\hline Toothbrushing status & & & & \\
\hline Yes & $4.53 \pm 3.34$ & \multirow{2}{*}{392} & \multirow{2}{*}{-2.848} & \multirow{2}{*}{.005} \\
\hline No & $5.83 \pm 3.82$ & & & \\
\hline Mouth rinsing condition & & & & \\
\hline Yes & $4.57 \pm 3.21$ & \multirow{2}{*}{392} & \multirow{2}{*}{-1.870} & \multirow{2}{*}{.062} \\
\hline No & $5.34 \pm 4.14$ & & & \\
\hline Have a toothbrush & & & & \\
\hline Yes & $4.49 \pm 3.27$ & \multirow{2}{*}{392} & \multirow{2}{*}{-3.400} & \multirow{2}{*}{.001} \\
\hline No & $6.07 \pm 4.09$ & & & \\
\hline Toothbrushing duration & & & & \\
\hline Less than $1 \mathrm{~min}$ & $5.03 \pm 3.38$ & \multirow{2}{*}{325} & \multirow{2}{*}{2.214} & \multirow{2}{*}{.028} \\
\hline At least $2 \mathrm{~min}$ & $4.19 \pm 3.26$ & & & \\
\hline Using dental floss & & & & \\
\hline Yes & $3.47 \pm 2.48$ & \multirow{2}{*}{24,953} & \multirow{2}{*}{-2.433} & \multirow{2}{*}{.022} \\
\hline No & $4.86 \pm 3.52$ & & & \\
\hline
\end{tabular}

As shown in Table 5, the difference between the mean DMFT scores of children toothbrushing status, having a toothbrush, toothbrushing duration for at least 2 minutes and using dental floss was statistically difference significant ( $p$ $<0.05)$.

Table6. Children's DMFT Points Averages According to Bad Oral Habits

\begin{tabular}{|l|l|l|l|l|l|l|}
\hline & & $\mathbf{N}$ & $\mathbf{\%}$ & $\begin{array}{l}\text { DMFT Point } \\
\text { average /sd }\end{array}$ & $\mathbf{t}$ & $\mathbf{p}$ \\
\hline Finger suction & Yes & 22 & 5.4 & $5.33 \pm 3.21$ & .609 & .436 \\
\cline { 2 - 8 } & No & 386 & 94.6 & $4.72 \pm 3.48$ & & \\
\hline \multirow{2}{*}{ Nail biting } & Yes & 87 & 21.32 & $4.96 \pm 3.72$ & .382 & .537 \\
\cline { 2 - 8 } & No & 321 & 78.7 & $4.70 \pm 3.39$ & & .687 \\
\hline \multirow{2}{*}{ Tooth grinding } & Yes & 77 & 18.9 & $4.90 \pm 3.29$ & 162 &. \\
\cline { 2 - 8 } & No & 331 & 81.1 & $4.72 \pm 3.50$ & & \\
\hline \multirow{2}{*}{ Tighten the teeth } & Yes & 91 & 22.3 & $4.88 \pm 3.23$ & .153 & .696 \\
\cline { 2 - 8 } & No & 317 & 77.7 & $4.72 \pm 3.53$ & & \\
\hline \multirow{2}{*}{$\begin{array}{l}\text { Using prolonged of } \\
\text { pacifiersand feeding } \\
\text { with bottle in infancy }\end{array}$} & Yes & 66 & 16.2 & $5.82 \pm 3.94$ & 7.211 & 0.008 \\
\hline \multirow{2}{*}{$\begin{array}{l}\text { Consuming junk food } \\
\text { every day }\end{array}$} & Yes & 342 & 83.8 & $4.55 \pm 3.33$ & & \\
\cline { 2 - 8 } & No & 228 & 55.9 & $5.11 \pm 3.67$ & 5.235 & 0.023 \\
\hline
\end{tabular}

ARC Journal of Nursing and Healthcare

Page $\mid 5$ 
Children's DMFT point averages according to badoral habits are shown in Table 6. DMFT point averages were significantly higher in children who using prolonged of pacifiers and feeding with bottle in infancy $(5.82 \pm 3.94)$ than don't using it $(4.55 \pm 3.33)$, and the difference was statistically significant $(\mathrm{p}=0.008)$. Similarly, the difference between DMFT average point of children who consuming junk food everyday $(5.11 \pm 3.67)$ and don't consuming $(4.31 \pm 3.13)$ were found statistically significant $(\mathrm{p}<0.05)$ in Table 6.

Table7. Correlation Between DMFT Point Average of Children and General Anxiety Sensitivity Index Total Point and Subscale Points

\begin{tabular}{|c|c|c|c|c|c|}
\hline & & $\begin{array}{l}\text { DMFT point } \\
\text { average }\end{array}$ & $\begin{array}{l}\text { Physical } \\
\text { Sensitivity }\end{array}$ & $\begin{array}{l}\text { Psychological } \\
\text { Sensitivity }\end{array}$ & $\begin{array}{l}\text { Social } \\
\text { Anxiety }\end{array}$ \\
\hline \multirow{3}{*}{$\begin{array}{l}\text { DMFT point } \\
\text { average }\end{array}$} & $\mathrm{r}$ & & $.108(*)$ & \begin{tabular}{|l|}
.092 \\
\end{tabular} & .091 \\
\hline & $\mathrm{p}$ & & .042 & \begin{tabular}{|l|l|}
.077 \\
\end{tabular} & .074 \\
\hline & $\mathrm{N}$ & & 394 & 394 & 394 \\
\hline \multirow[t]{3}{*}{ Physical Sensitivity } & $\mathrm{r}$ & $.108(*)$ & & $.579(* *)$ & $.540(* *)$ \\
\hline & $\mathrm{p}$ & .042 & & .000 & .000 \\
\hline & $\mathrm{N}$ & 394 & & 408 & 408 \\
\hline \multirow{3}{*}{$\begin{array}{l}\text { Psychological } \\
\text { Sensitivity }\end{array}$} & $\mathrm{r}$ & .092 & $.579(* *)$ & & \begin{tabular}{|l}
$.506(* *)$ \\
\end{tabular} \\
\hline & $\mathrm{p}$ & .077 & .000 & & .000 \\
\hline & $\mathrm{N}$ & 394 & 408 & & 408 \\
\hline \multirow{3}{*}{$\begin{array}{l}\text { Social } \\
\text { Anxiety }\end{array}$} & $\mathrm{r}$ & .091 & $.540(* *)$ & \begin{tabular}{|l|}
$.506(* *)$ \\
\end{tabular} & \\
\hline & $\mathrm{p}$ & .074 & .000 & \begin{tabular}{|l|}
.000 \\
\end{tabular} & \\
\hline & $\mathrm{N}$ & 394 & 408 & 408 & \\
\hline \multirow{3}{*}{$\begin{array}{l}\text { General Scale Total } \\
\text { Score }\end{array}$} & $\mathrm{r}$ & $.114(* * *)$ & $.893(* * * *)$ & $.828(* * * *)$ & $.760(* * * *)$ \\
\hline & $\mathrm{p}$ & .037 & .000 & .000 & .000 \\
\hline & $\mathrm{N}$ & 394 & 408 & 408 & 408 \\
\hline
\end{tabular}

Table 7 provides a correlation analysis for DMFT points and general anxiety sensitivity index total point and subscale points. According to this,

* There is a positive and weak relationship between DMFT point average and physical sensitivity score. As the average DMFT score increases, the physical sensitivity score will increase at a weaker rate.

** There is a positive and moderate relationship between physical sensitivity and psychological sensitivity and social anxiety. Each of these increases or decreases affects the other moderately in the positive direction.

*** There is a positive and weak relationship between anxiety sensitivity general scale total point average and DMFT points.

**** It has been determined that there is a positive and strong relationship between the total score of anxiety sensitivity scale and the subscale point averages.

\section{DISCUSSION}

Tooth decay is an important public health problem as a pandemic, high prevalent chronic illness in many developed and developing countries. This is attributed to increasing sugar consumption and lack of fluoride $[8,9,21]$. In our study, the major cause of admission to hospital of the children was tooth decay with $25 \%$. $55.9 \%$ of the children were consuming junk food every day as show in Table 6.The DMFT average of children who consumed junk food every day was very high found as $5.11 \pm$ 3.67 in Table 6.In Gökalp and Doğan's study (2004), which examined to treatment needs of 512 and 15 years old children and 35-44 years old and 65-74 years old adult $(\mathrm{n}=7833)$, it found that tooth decay rate of 5 years old was $69.8 \%$, 12 years old was $61.1 \%$, and 15 years of age was $66.4 \%$ [22]. Jessri et al. (2013) found DMFT mean of $2.51 \pm 2.14$ in school children aged 9-13 in Tehran $(n=1271)$ [23] and Borges et al (2016) in Brazil with 623 students in the 10-17 age group reported an average DMFT of 2.5 [24]. Koçanlı et al. (2014) found a positive correlation between the frequency of dietary food intake and child caries index values in their study with 300 children aged 7-13 years [25]. Moynihan et al. (2014) in a systematic review of their relationship between sugar consumption and dental decay, the reduction of daily consumption of sugar has also been associated with a reduction in risk of dental decay [26].Gökalp et al. (2007) found that, among the 4657 children between the ages of 5 and 15 years, $1.4 \%$ of the 12 -year-olds went to the dental clinic regularly and $89.4 \%$ had 
toothbrushes. It was also found that snacking of sugary foods / drinks among the meals in all age groups took place in the first place. The DMFT average for $12(\mathrm{n}=1611)$ years was $1.9 \pm 2.2$ [22]. Taşveren et al. (2005) The average DMFT score in the 12-year-old $(\mathrm{n}=114)$ children was $3.58 \pm 1.69$ [27]. Namal and colleagues (2009) found that the mean value of DMFT was very high $(8.72 \pm 2.05)$ when studying with 117 children between 6-12 years old in Istanbul [28]. Eğri et al. (2015), DMFT was found to be $3.33 \pm$ 2.15 in 300 students at the age of 12 years [29]. It can be said that our work supports these studies.

In our study, the frequency of routine visits to the dental clinic / every 6 months was very low with $13 \%$ in Table 5.Yurdasal et al. (2012) found at least one permanent tooth decay in $41.4 \%$ of school children and at least one deciduous tooth decay in $83.8 \%$ of school children in Denizli. The mean per tooth decay per student was $4.8 \pm 3.5$ [30]. In our study, $83.4 \%$ of the children were found to brush their teeth. The regular brushing rate of children twice a day was $71.8 \%$ (See Table 2).This high ratio can be a result of our University Dental Faculty's preventive oral-dental health care project, which has been carried out by preschool and primary school classes since 2008 [31].However, in our study, the DMFT average $(4.75 \pm 3.46)$ shows that children's oral-dental health problem persists despite this struggle in the region, similar to that of Yurdasal and colleagues (4.8 \pm 3.5$)$. Yahyaoğlu et al. (2017), show that 810 children between 6 and 12 years of age were administered the "Child Fear Rating Scale-Dental Subscale (CFSS-DS)" and the DMFT / DMFT indexes were determined by performing oral-dental examinations of the patients, the mean DMFT of children aged 6-8 years is found to be higher than that of children aged 9-12 years [32]. In our study, the mean DMFT score of children aged 7-9 was found as $5.37 \pm 3.46$, and there were statistically important different according to the other ages ( $p$ <0.05). It can be said that our work supports these studies.

In the literature, there are many studies on dental anxiety in children. These studies show that oral health is also closely related to anxiety $[18,33,34]$. Folayan et al. (2003) conducted a study with 81 children aged 8-13 years using the Child Fear Rating Scale-Dental Subscale (CFSS-DS), found that very few of the children had high level of dental anxiety as in $14.8 \%(\mathrm{n}=$
18) [34]. A systematic review of dental fear / anxiety and behavior problems by children and adolescents conducted by Klinberg and Broberg (2007) using the PUBMED database between 1982 and 2006 showed that $9 \%$ of children in Australia, Canada, Europe and the United States had dental fear / anxiety and behavior problems, and this frequency was found to increase with age. In the same review, $64 \%$ of children reported moderate levels of dental fear / anxiety [35]. In the study conducted by Assunção and Losso (2013) at the Parana Federal Children's Clinic in Brazil using the Corinthian Dental Anxiety Scale (DAS) and STAI on children aged 8-17 years; $54 \%$ of children were found moderate anxiety, and $39 \%$ had a moderate DAS score [36].In our study, when physical, psychological sensitivity and social anxiety levels of the anxiety sensitivity index subscale were examined $(68.4 \% \mathrm{n}=279)$, it was found that children who had anxiety before the procedure had higher anxiety points and that the difference was statistically significant $(\mathrm{p}=$ 0.000) (see Table 4). This finding can be interpreted that children who were anxious before the procedure were more likely to be distressed and affected the child in all dimensions. Rantavouri et al. (2004) found that children were affected by age related dental fear in 1474 children, $3-15$ years old using the Child Fear Rating Scale (CFSS-DS) in Finland. In their study, the 3-6 years age group children had more dental anxiety[37].Taani et al. (2005) found that girls were more likely to have higher levels of fear than boys on 1021 children aged 12-15 years in Jordan [ 38].Similarly, Önça ğ and Çoğulu (2005) found that the dental fear level of girls was higher than in boys on 120 children aged 3-12 years who applied to the Pedodontics Clinic, using the Child Fear Rating Scale (CFSS-DS) [39].Oba et al. (2009) reported that the highest score $(45.8 \pm 10.061)$ was 7 years old and the lowest score $(38.0 \pm$ 0.00 ) was 11 years old in the study conducted by using the Child Fear Rating Scale (CFSSDS) with 275 children aged 7-11 in a primary school in Kirikkale, the difference was found to be significant [33].In our study, the difference between the mean scores of the general scale of the children aged 7-9 $(45.46 \pm 11.87)$ and the other age groups was statistically significant ( $p$ $<0.05$ ) in Table 3. The result of this study supports the results of the above studies and it can be said that the age of children affected the level of dental anxiety. On the other hand, in our study, gender was not effective found. 
In this study, the difference between anxiety sensitivity index total scores according to the explanation of the process doing to children and unexplained group $42.59 \pm 11.04$ was found statistically significant $(\mathrm{p}<0.05)$. Based on this finding, it can be said that the explanation of the operation is to reduce the anxiety of the children. In addition, it was determined that the mothers' working affected the DMFT point average of children. Borges et al. (2015) in study of 623 students aged 10-17 in Brazil reported a significant difference in the percentage of children whose mothers completed their 4-year educational life [24]. In our study, the difference between the educational background of parents and DMFT point average of children was not significant. It has been determined by Egri et al. (2015) that the level of education of the mother influences the average DMFT score of the children at 26 school on 12 years old children with 300 students [29].

Carrillo-Diaz et al. (2015) found that those who went to dental clinics with 250 school children in Madrid, Spain, were statistically significant when compared to the DMFT index and the number of dental caries in the regular dentist. Going to an irregular dentist was also associated with fear that they increased tooth decay by $20 \%$ [40]. Jessri and colleagues (2013) found that about half of the children $(47.52 \%)$ reported that they received oral dental health education from school and only $10.6 \%$ from dentists when they were working with 1271 children aged 9-13 at 16 primary schools in Tehran. Children receiving education were found to have lower rates of decay [23].In our study, the proportion of children receiving oral dental health education was $52.5 \%$, and the proportion of those receiving education from school was $74.3 \%$.Also, in our study it was determined that toothbrushing is important in preventing tooth decay. In similar studies, Taşveren et al. (2005) investigated the difference between the mean DMFT scores according to toothbrushing status in 12-year-old children and found that the difference was significant. Children who never brush their teeth were found to have a higher average DMFT score than children who brush twice a day [27]. Jessri et al. (2013) found that children who did not brush their teeth were significantly more likely to have tooth decay, severe bruising and gingivitis at a statistically significantly higher rate than children who brush their teeth [23]. The findings of these studies support our work. Creeth et al reported that the longest tooth brushing time (180 seconds) removed $55 \%$ of the tooth plaque over the shortest tooth brushing period (30 seconds) in the study that investigated the in vivo effect of brushing time and dentifrices on dental plaque removal. They determined that the 2-minute toothbrushing period removed $26 \%$ more tooth plaque than the 45 -second toothbrushing [41].

In this study, some oral habits of children are also examined. The proportion of children using prolonged a pacifier-bottleis $16.17 \%(\mathrm{n}=66)$. The difference between the DMFT point average $(5.8254 \pm 3.94)$ and the DMFT average (4.5559 \pm 3.33$)$ for prolonged nipple drinkers and long-term nipple drinkers was found to be statistically significant $(\mathrm{p}=0.008)$ (see Table 6).It can be highlighted that it should be avoid for protecting the dental health of the children than using bottle for prolonged time. The mean age of starting tooth brushing in our study was found to be $2.18 \pm 0.89$. In the literature, the average age of onset of tooth care is 6 months, when the first milk teeth start to run. In this period, dental care is recommended by the parent with a soft cloth / gauze [42].In this study, there is a low level relationship between anxiety sensitivity general scale total point average and DMFT point average in positive direction. According to this, it can be said that as the anxiety increases, the DMFT point average will increase (see Table 7).

\section{CONCLUSION}

As a result, this study suggests that prepreparation of the child according to the age and developmental characteristics of the children in pedodontics outpatient clinics is recommended because it is determined that the anxiety level is reduced in the pre-prepared children. In this study, there is an association between age and DMFT and anxiety levels, it is necessary to choose oral dental health education methods appropriate to children's age and developmental characteristics. Families should be conscious about DMFT is high in children who using a long time pacifier, bottle during infancy and who consuming large quantities of junk foods every day. The fact that children have first-line dental caries and the screening of oral-dental health among the reasons for referral to the hospital shows that the necessary preventive measures are insufficient. There is a need to expand protective oral and dental health services. 


\section{REFERENCES}

[1] http://www.who.int/oral_health/action/informat ion/surveillance/en 2.5.2017

[2] http://www.who.int/oral_health/events/liverpoo 1 declaration/en/2.05.2017

[3] http://www.who.int/oral_health/publications/go als2020/en/

[4] http://www.who.int/nmh/countries/tur_en.pdf?u $\mathrm{a}=1$.2.5.2017

[5] Doğan B., Gökalp S., Türkiye'de Diş Çürüğü Durumu ve Tedavi Gereksinimi, 2004, Hacettepe Diş Hekimliği Fakültesi Dergisi, 2008; 32(2):45-57.

[6] Rafael da SilveiraMoreira. Epidemiology of DentalCaries in the World, Oral HealthCare Pediatric, Research, Epidemiology and ClinicalPractices, Prof. Mandeep Virdi (Ed.), Published online 29, February, 2012, ISBN: 978-953-51-0133-8, InTech, Available from: http://www. İntech open .com/ books/ oralhealth-care-pediatric- research- epidemiologyandclinical-practices/ epidemiology-of-dentalcaries- in-the-world. 16.05.2017.

[7] Petersen PE., Bourgeois D., Ogawa H., Estupinan-DaY S. andNdiaye C. The global burden of oral diseasesandrisksto oral health, Bulletin of the World HealthOrganization | September. 83 (9):661-669 (2005).

[8] Petersen PE, Lennon MA. Effective use of fluorides for the prevention of dental caries in the 21st century: the WHO approach. Community Dent Oral Epidemiol, Blackwell Munksgaard 32 (5): 319-21 (2004).

[9] Petersen PE, Hoerup N, Poomviset N, Prommajan J, Watanapa A, Oral Health Statusand Oral HealthBehaviour of Urban andRuralSchoolchildren in SouthernThailand, Int. Dental Journal. 51 (2):95-102(2001).

[10] Popescu Sm., Dascălu It, Scriecıu M., Mercuţ V., Imoraru I. and ȚuculınăMj., Dental Anxiety and its Association with Behavioral Factors in Children, Current Health Sciences Journal. 40 (4): 261-264 (2014).

[11] Schuller AA, Willumsen T, Holst D. Are there differences in oral health and oral health behavior between individuals with high and low dental fear? Community Dent Oral Epidemiol. 31 (2):116-121 (2003).

[12] Esa R., SavithriV.,Humphris G.,Freeman R. The relationship between dental anxiety and dental decay experience in antenatal mothers. European Journal of Oral Sciences. 118(1): 5965 (2010).

[13] T.C. Sağlık Bak. Sağlık İstatistikleri Yıllığı 2015, http://www.tuik.gov.tr16.06.2017

[14] ÇubukcuElbek Ç., Ercan İ. Tıp Fakültesi Bünyesindeki Ağız ve Diş Sağlı̆̆ı Birimine
Başvuran Çocuklarda Sosyodemografik Faktörlerin DentalAnksiyete Üzerine Etkisi. J Curr Pediatr. 6: 53-5 (2008).

[15] Ayrancı Ü., Bir Grup İlkokul Öğrencisinde Diş Çürüğü Saptama Araştırması, STED. 14(3): 5054(2005).

[16] Bayrak Ş., Şen Tunç E.,Eğilmez T., Tüloğlu N., Ebeveyn Dental Kaygisı ve Sosyodemografik Faktörlerin Çocukların Dental Kaygısı Üzerine Etkileri, Atatürk Üniv. Diş Hek. Fak. Derg. 20(3):181-188 (2010).

[17] KırbaşÖzlem Z., Özkan H., Ağız ve Diş Sağlığı Merkezine Başvuran 9-12 yaş Grubu Çocukların Durumluk Kayg1 Düzeylerinin Belirlenmesi, İzmir Behçet Uz Çocuk Hast. Dergisi 2014;4(2):128-134.

[18] Glick M., Monteiro O., Seeberger G., Xu T., Pucca G., Williams D., Kess S., Eiselej., Severin T. FDI vision 2020: shaping the future of oral health international dental journal 2012; 62: 278-291.

[19] Öztaş D.,Demiralp KÖ.,GüzeldemirciG.,Üstü Y.,Doğusan AR.,KarahanS.,Ar1 HO, Özgül E.,Kartal İ,Uğurlu M. Türkiye'de Ağız ve Diş Sağlığı Merkezlerindeki Hizmetlerin Finansmanı ve Harcamaların Değerlen dirilmesi. Ankara Med J, 2016; 16(2): 170-81

[20] Seçer İ, Gülbahçe A. (2013). Çocuklarda Anksiyete Duyarlılık Ölçeğinin Türk Kültürüne Uyarlanması: Güvenirlik ve Geçerlilik Çalışması, Middle Eastern \& AfricanJournal of EducationalResearch, (3): 91-106.

[21] Masood M, Masood Y, Newton T, Impact of NationalIncomeandInequality on Sugarand Caries Relationship, CariesRes 2012;46:581588.85 .

[22] Gökalp S., Doğan B., Tekçiçek M., Berberoğlu A., Ünlüer Ş., Beş, On İki ve On Beş Yaş çocukların ağız diş sağlığı profili, Türkiye2004, Hacettepe Diş Hekimliği Fakültesi Dergisi, 2007,31(4): 3-10

[23] Jessri Mah., Jessri Mar., Rashidkhani B., Kimiagar S-M., Oral healthbehaviours in relation to caries and gingivit is in primaryschoolchildren in Tehran, Eastern Mediterranean Health Journal, 2008, 19(6):

[24] Borges TS., Schwanke NL, Reuter CP, Neto LK, Burgos MS., Factorsassociatedwithcaries: a survey of studentsfromsouthernBrazil, Rev Paul Pediatr. 2016;34(4):489-494.

[25] Koçanlı B., Ak A., Çoğulu D., Çocuklarda Diş Çürüğüne Neden Olan Faktörlerin İncelenmesi, TheJournal of PediatricResearch 2014;1(2):769

[26] Moynihan PJ, Kelly SAM, Effect on Caries of RestrictingSugarsIntake: Systematic Review to Inform WHO Guidelines, J DentRes 2014, 93(1):8-18. 
[27] Taşveren S., Yeler D., Sözen A., Taşveren S. 12 Yaş Grubu Çocukların Diş Fırçalama Sıklı̆̆ı-DMFT İlişkisi, Atatürk Üniv. Diş. Hek. Fak Dergisi; 2005,15(3):11-14,

[28] Namal N., Vehid H., Vehid S., Can G., Altı-On iki Yaş Grubu Çocukların Diş Sağlı̆̆ını Etkileyen Anneye Ait Faktörlerin Araştırılması, Çocuk Dergisi, 2009;9(3):123-126

[29] Eğri M., Kayaoğlu A., Önder Y., Çıtıl R., Tokat İ Merkezindeki İlköğretim 12 Yaş Öğrencilerde DMFT İndeksi ve İlişkili Faktörler, Gaziosmanpaşa Üniversitesi Tıp Fakültesi Dergisi 2015;7 (3): 198-207.

[30] Yurdasal B, Bozkurt Aİ, Öz İ, Tanrıverdi S, Taş E, Nalbant M. Denizli Ağız Diş Sağlığını Geliştirme Projesi; 3. Y1l Sonuçları. Türkiye Halk Sağlığı Dergisi 2012;10(1).

[31] Dülgergil ÇT, Ercan E, Colak H, Evaluation of schoolbasedprevention program in Turkey: Results of a 24 monthstudy, Eur J Dent 2016;10:245-9.

[32] Yahyaoğlu Ö, Baygın Ö, Yahyaoğlu G, Tüzüner T, 6-12 Yaş Grubu Çocuklarda Diş Hekiminin Dış Görünüşünün Dental Korku ve Diş Çürüğü ile İlişkisinin Değerlendirilmesi, Atatürk Üniversitesi Diş Hekimliği Fakültesi Dergisi, 2017.

[33] Oba A., Dülgergil ÇT., Sönmez I., Prevalence of DentalAnxiety in 7- to 11-Year-Old Children and Its Relationship to DentalCaries, Med PrincPract 2009, 18:453-457

[34] Folayan M.O., Idehen E.E., Ufomata D., TheEffect of Socio demographic Factors on Dental Anxiety in Children Seen in a Suburban Nigerian Hospital, International Journal of PaediatricDentistry 2003; 13: 20-26.

[35] Klingberg G., Broberg AG., Dental Fear/ Anxiety and Dental Behaviour Management
Problems in Children And Adolescents: A Review of Prevalence and Concomitant Psychological Factors. Int J PaediatrDent, 2007; 17(6):391-406.

[36] Assunção CM, Losso EM., AndreatiniR. ,Menezes J., The Relationship Between Dental Anxiety in Children, Adolescents and Their Parents at Dental Environment, Journal of IndianSociety of Pedodontics and Preventive Dentistry, 2013, Jul-Sep, 31;3:174-179.

[37] Rantavouri K., Lahti S., Hausen H., Seppä L., Kärkkäinen S., Dentalfearand oral health and family characteristics of finnish children. Actao dontolojicascandinavica, 2004;62:207-213

[38] Taani DQ, El-Qaderi SS, Abu Alhaija ESJ, DentalAnxiety in Children and İts Relationship to Dental Caries and Gingival Condition, Int J DentHygiene 3, 2005: 83-87.

[39] Önçağ Ö., Çoğulu D., Ailenin Sosyoekonomik Durumu ve Eğitim Düzeyinin Çocuklarda Dental Kayg1 Üzerine Etkisi, A.Ü. Diş Hek. Fak. Derg., 2005, 32(1) 45-54

[40] Carrillo-Diaz M, Crego A, Armfield JM, Romero M. Dentalfear-related cognitive vulnerability perceptions, dental prevention beliefs, dentalvisiting, andcaries: a crosssectionalstudy in Madrid. CommunityDent Oral Epidemiol 2015; 43: 375-384.

[41] Creeth J, Gallagher A, Swonski J, Bowman J, Barrett K, Lowe S, Patel K, Bosma M, TheEffect of Brushing Time andDentifrice on DentalPlaqueRemoval in vivo, TheJournal of DentalHygiene, 2009, 83(3): 111-116.

[42] Erdem Y. Çocuk Gelişimi Bölümleri İçin Çocuk Hastalıkları Kitabı, Vize Yayıncılık, 4. Bask1, Ankara, 2015.

Citation: Eda TÖREDI, Prof. Yurdagül ERDEM, Dental Anxiety Levels and Affecting Factors in 7-14 Years Old Children, ARC Journal of Nursing and Healthcare. 2017; 3(3): 1-10. doi: dx.doi.org/ 10.20431/24554324.0303001.

Copyright: (C) 2017 Authors. This is an open-access article distributed under the terms of the Creative Commons Attribution License, which permits unrestricted use, distribution, and reproduction in any medium, provided the original author and source are credited. 